\title{
Registration of 'Northern' Hard Red Winter Wheat
}

\author{
Authors: Jim E. Berg, P. F. Lamb, John H. Miller, \\ David M. Wichman, Ken D. Kephart, R. N. Stougaard, \\ G. P. Pradhan, Deanna L. Nash, William E. Grey, D. \\ Gettel, S. Gale, Y. Jin, J. A. Kolmer, X. Chen, G. Bai, \\ T. D. Murray, and Phil L. Bruckner
}

This is a postprint of an article that originally appeared in Journal of Plant Registrations on April 15, 2016.

Berg, Jim E, P F Lamb, J H Miller, D M Wichman, K D Kephart, R N Stougaard, G P Pradhan, Deanna L Nash, William E Grey, D Gettel, S Gale, Y Jin, J A Kolmer, X Chen, G Bai, T D Murray, and Phil L Bruckner. "Registration of 'Northern' Hard Red Winter Wheat." Journal of Plant Registrations 10, no. 2 (May 2016): 135-138. DOI: 10.3198/jpr2015.10.0062crc.

Made available through Montana State University's $\underline{\text { ScholarWorks }}$ scholarworks.montana.edu 


\title{
Registration of 'Northern' Hard Red Winter Wheat
}

\author{
J. E. Berg, P. F. Lamb, J. H. Miller, D. M. Wichman, K. D. Kephart, R. N. Stougaard, G. P. Pradhan, D. L. \\ Nash, W. E. Grey, D. Gettel, S. Gale, Y. Jin, J. A. Kolmer, X. Chen, G. Bai, T. D. Murray, and P. L. Bruckner*
}

\begin{abstract}
J.E. Berg, D.L. Nash, W.E. Grey, and P.L. Bruckner, Dep. of Plant Sciences \& Plant Pathology, Montana State Univ., Bozeman, MT 59717-3140; P.F. Lamb, Northern Agricultural Research Center, 3710 Assinniboine Rd., Havre, MT 59501-8412; J.H. Miller, Western Triangle Agricultural Research Center, 9546 Old Shelby Rd., Conrad, MT 59425; D.M. Wichman, Central Agricultural Research Center, 52583 US Hwy. 87, Moccasin, MT 59462; K.D. Kephart, Southern Agricultural Research Center, 748 Railroad Hwy., Huntley, MT 59037; R.N. Stougaard, Northwestern Agricultural Research Center, 4570 Montana 35, Kalispell, MT 59901; G.P. Pradhan, Williston Research Extension Center, 14120 Hwy. 2, Williston, ND 58801; D. Gettel, Montana Agricultural Experiment Station, Bozeman, MT 59717; S. Gale, Y. Jin, and J.A. Kolmer, USDA-ARS, Cereal Disease Lab., 1551 Lindig St., St. Paul, MN 55108-6052; X. Chen, USDA-ARS, P.O. Box 646430, Pullman, WA 99164-6430; G. Bai, USDA-ARS, Hard Winter Wheat Genetics Research Unit, 4008 Throckmorton Hall, Manhattan, KS 66506; T.D. Murray, Dep. of Plant Pathology, Washington State Univ., Pullman, WA 99164-6430.
\end{abstract}

\begin{abstract}
'Northern' (Reg. No. CV-1114, PI 676026) hard red winter wheat (Triticum aestivum L.) was developed and released by the Montana Agricultural Experiment Station in 2015. Northern was derived from a composite of two crosses, MT9982//MTW0072/NW97151 and MTW0047//MTW0072/NW97151. Northern was developed using a modified bulk breeding method and selected as an $F_{5: 7}$ headrow. Northern was tested under the experimental number MT0978 in Montana yield trials from 2009 to 2015. Like predominant cultivar Yellowstone, Northern is a high-yielding, winter-hardy hard red winter wheat cultivar with medium to late maturity, medium to high grain protein, and acceptable milling and baking quality. Northern was released for its excellent performance in winter wheat production environments of north-central Montana, reduced plant height, and improved grain volume weight and resistance to stem rust (caused by Puccinia graminis Pers.:Pers. f. sp. tritici Eriks. \& E. Henn.) relative to Yellowstone.
\end{abstract}

'N ORTHERN' (Reg. No. CV-1114, PI 676026) hard red winter wheat (Triticum aestivum L.) was developed and released by the Montana Agricultural Experiment Station in 2015. Northern was named in honor of the centennial of the establishment of the Northern Agricultural Research Center (originally designated Northern Branch Station) near Havre, MT, in 1915. Northern Agricultural Research Center is located in Montana's primary winter wheat production area and is an important selection and evaluation site contributing to the development of improved wheat cultivars. Northern was released for its excellent combination of winter wheat production characteristics suited for north-central Montana, including reduced plant height, improved grain volume weight, and resistance to stem rust (caused by Puccinia graminis Pers.:Pers. f. sp. tritici Eriks. \& E. Henn. [Pgt]) compared with the predominant cultivar Yellowstone.

\section{Methods}

\section{Pedigree and Breeding History}

Northern was developed from a composite of two topcrosses made to the same $F_{1}$ population, MT9982//MTW0072/ NW97151 and MTW0047//MTW0072/NW97S151, using a modified bulk breeding method. MT9982 is an unreleased, sib selection of Yellowstone (PI 643428; Bruckner et al., 2007). MTW0072 is an unreleased breeding line with the pedigree MT8709 ('Erhardt' [PI 564761; Wichman et al., 1997] sib)/NuWest [PI 586806; Bruckner et al., 1996]//

Abbreviations: LY, location years; MSU, Montana State University; Pgt, Puccinia graminis f. sp. tritici; NRPN, Northern Regional Performance Nursery. 
Erhardt. NW97S151 (KSSB-192-3/NE89529) is an unreleased breeding line developed by the USDA-ARS program at Lincoln, NE. MTW0047 is an unreleased breeding line with the pedigree 'Judith' [PI 584526; Taylor et al., 1995]/PI 262605// S86-740 (S86-740, developed at Saskatoon, Sask., has the pedigree 'Norstar'[CI 17735; Grant, 1980]/'Plainsman V' [PI $591702] / /(U l i a n o v k a ')$. The $F_{1}$ population was grown at Bozeman, $\mathrm{MT}$, in 2001. $\mathrm{F}_{2}, \mathrm{~F}_{3}, \mathrm{~F}_{4}$, and $\mathrm{F}_{5}$ bulk populations were grown at Fort Ellis, MT, Williston, ND, North Havre, MT, and Bozeman, MT, from 2002 to 2005, respectively, with mass selection for winter survival, reduced plant height, favorable head morphology, and kernel plumpness. One hundred fourteen heads were selected from the $F_{5}$ population in 2005 and grown as $F_{6}$ headrows at Bozeman in 2006. Headrow 00X248cE97 was selected on the basis of visual evaluation for uniformity, productivity, and acceptable agronomic type, and four individual heads were harvested for a second round of headrow selection. $\mathrm{F}_{7}$ headrows were evaluated in 2007, and headrow 00X248cE97-2 was selected and harvested in bulk.

\section{Line Selection and Evaluation}

In 2008, 00X248cE97-2 was tested in the Single Rep A Observation Nursery at Bozeman, Moccasin, Conrad, and Fort Ellis, MT. In 2009, 00X248cE97-2 was designated MT0978 and subsequently tested in the 2009 Montana State University (MSU) Preliminary A Yield Trial (3 location years [LY]), the 2010 MSU Advanced Yield Trial (5 LY), the MSU Intrastate Trial from 2011 to 2014 (28 LY), and the MSU Off-Station Trial in 2013 and 2014 (28 LY). Milling and baking quality have been evaluated in multilocation Montana trials since 2009. In 2013, MT0978 was an entry in the USDA Northern Regional Performance Nursery (NRPN) planted at approximately 20 sites across the northern Great Plains. Northern was also evaluated in the 2012 Hard Winter Wheat Quality Council evaluation.

The Montana Intrastate Trial consisted of 49 entries planted in partially balanced lattice or randomized complete block designs with three replications. Plot size, row number, and row spacing varied by location due to variable plot seeding equipment. Seeding rate was approximately 2.15 million kernels ha ${ }^{-1}$. The Montana Off-Station Nursery consisted of 24 entries planted in on-farm randomized complete block design trials with three replications, planted at 2.15 million kernels $\mathrm{ha}^{-1}$. Grain yield, volume weight, plant height (distance from ground to top of spike excluding awns), and grain protein were measured in all environments. Days to heading ( $50 \%$ of heads in plots completely visible) was recorded in most on-station trials.
Winter survival (\% plants surviving), lodging (\% plants lodged), and stripe rust (caused by $P$. striiformis Westend. f. sp. tritici Eriks.) (\% severity) were recorded in environments where there was differential expression for these traits. Coleoptile length was determined under controlled growth room conditions at Bozeman.

Milling and baking characteristics were determined by the Montana State University Cereal Quality Laboratory using methods approved by the American Association of Cereal Chemists International (2000). Grain protein was determined using an Infratec 1225 Grain Analyzer (Foss Analytical). Kernel hardness was determined using a single-kernel characterization system (SKCS-4100, Perten Instruments). Composite grain samples harvested at four locations of the Montana Intrastate Trial in 2011, 2012, and 2013 were milled on a Brabender Automat mill (C.W. Brabender), and the flour was used to determine bake absorption, mix time, and loaf volume (American Association of Cereal Chemists Method 10-10B).

Analysis of variance was conducted on data from individual environments and across environments using SAS version 9.2 (SAS Institute, Cary, NC). Mean comparison of traits using a protected LSD $(P=0.05)$ test was made to identify significant differences among genotypes. The genotype environment mean square was used to estimate the standard error of differences when comparing genotype means across environments.

\section{Seed Purification and Increase}

Purification and increase of Northern was initiated in 2011 when $120 \mathrm{~F}_{5}$-derived $\mathrm{F}_{10}$ headrows were grown with selection for visual uniformity, retaining 83 line rows that were bulked as a source of breeder seed. Breeder seed of Northern was increased in 2012. Foundation seed of Northern was produced in 2014.

\section{Agronomic Characteristics}

Northern is an awned, white-glumed, hard red winter wheat. In Montana, Northern has medium-late maturity, 169 $\mathrm{d}$ to heading from 1 January, similar to Yellowstone and 3 to $4 \mathrm{~d}$ later $(P<0.05)$ than 'Jagalene' (PI 631376), 'CDC Falcon' (PI 619610), and 'Decade' (PI 660291, Riveland et al., 2011) (Table 1). Northern is a tall $(81 \mathrm{~cm}, n=56) \operatorname{semidwarf}(R b t B 1 b)$ cultivar, $4 \mathrm{~cm}$ shorter $(P<0.05)$ than Yellowstone, similar in height to Jagalene and Decade, and $4 \mathrm{~cm}$ taller than CDC Falcon. Coleoptile length of Northern under controlled conditions is $64 \mathrm{~mm}$, similar to Yellowstone $(69 \mathrm{~mm})$, but shorter $(P$ $<0.05)$ than CDC Falcon $(74 \mathrm{~mm})$, Decade $(81 \mathrm{~mm})$, and Jagalene $(84 \mathrm{~mm})$ (data not shown). Winter survival of Northern in

Table 1. Mean performance of hard red winter wheat cultivar Northern and check cultivars in 56 Montana environments, $2011-2014$.

\begin{tabular}{|c|c|c|c|c|c|c|c|c|}
\hline Cultivar & Grain yield & Volume weight & Winter survival & Heading date & Plant height & Lodging & Grain protein & Stripe rust \\
\hline & $\mathrm{kg} \mathrm{ha}^{-1}$ & $\mathrm{~kg} \mathrm{~m}^{-3}$ & $\%$ & d from 1 Jan. & $\mathrm{cm}$ & $\%$ & $\mathrm{~g} 100 \mathrm{~g}^{-1}$ & $\%$ severity \\
\hline Yellowstone & 4838 & 764 & 33 & 168.0 & 85 & 11 & 12.9 & 31 \\
\hline Colter & 4797 & 770 & 38 & 168.4 & 85 & 11 & 13.1 & 23 \\
\hline Northern & 4757 & 770 & 34 & 168.5 & 81 & 14 & 13.2 & 28 \\
\hline Jagalene & 4576 & 794 & 26 & 164.5 & 80 & 12 & 12.8 & 37 \\
\hline CDC Falcon & 4287 & 763 & 47 & 165.8 & 76 & 7 & 12.9 & 55 \\
\hline Decade & 4213 & 763 & 49 & 165.0 & 81 & 13 & 13.3 & 72 \\
\hline LSD (0.05) & 255 & 8 & 13 & 0.5 & 1 & ns & 0.2 & 13 \\
\hline $\begin{array}{l}\text { No. of } \\
\text { environments }\end{array}$ & 56 & 56 & 4 & 31 & 56 & 12 & 55 & 6 \\
\hline
\end{tabular}


environments with differential survival was similar to Jagalene and Yellowstone but lower $(P<0.05)$ than CDC Falcon and Decade (Table 1). Northern is well adapted to all areas of Montana, including eastern areas that require higher levels of winter hardiness.

Northern has been genetically uniform and stable over three generations of seed increase, with few visually obvious plant variants. Northern contains a tall plant variant at a frequency less than 15 per 10,000 plants.

\section{Field Performance}

In $56 \mathrm{LY}$ of testing in the Montana Winter Wheat Intrastate and Off-Station nurseries, average yield of Northern $(4757 \mathrm{~kg}$ $\mathrm{ha}^{-1}$ ) was high, similar to the yield of Yellowstone and Colter (PI 670156; Berg et al., 2014), and higher $(P<0.05)$ than the yields of CDC Falcon and Decade (Table 1). Volume weight of Northern $\left(770 \mathrm{~kg} \mathrm{~m}^{-3}\right.$ over $\left.56 \mathrm{LY}\right)$ was medium to high, similar to Yellowstone, CDC Falcon, Colter, and Decade but lower $(P$ $<0.05$ ) than that of Jagalene (Table 1). Grain protein content of Northern was higher $(P<0.05)$ than Jagalene, CDC Falcon, and Yellowstone and similar to Colter and Decade (Table 1).

\section{Disease and Insect Resistance}

Characterization of Northern for disease and insect resistance included Montana trials and cooperative evaluations by the USDA Regional Testing Program. Northern is susceptible to Russian wheat aphid (Diuraphis noxia Mordvilko), wheat stem sawfly (Cephus cinctus Norton), and Hessian fly [Mayetiola destructor (Say)]. Northern is moderately resistant to stem rust based on field and seedling evaluations conducted at Bozeman, MT using Pgt TMLKC and QFCSC and seedling and field stem rust evaluations conducted by the USDA-ARS Cereal Disease Laboratory in 2010, 2011 (Regional Germplasm Observation Nursery), and 2013 (NRPN). In seedling evaluations at St. Paul, MN, Northern was susceptible to Pgt races RCRSC, RKQQC, TPMKC, and TTTTF and resistant to races QFCSC, QTHJC, MCCFC, SCCSC, and QCCSM. Northern was resistant to races TTKSK, TTKST and TTTSK of the Ug99 race group, postulated to be due to $\operatorname{Sr} 36$ and $\operatorname{Sr} \operatorname{Tm} p$. Field adult-plant evaluations using a bulk of races QFCSC, QTHJC, RCRSC, RKQQC, and TPMKC in 2010, 2011, and 2013 at St. Paul indicated Northern was moderately to highly resistant. Field evaluation at Njoro, Kenya, indicated Northern was moderately resistant to Ug99 races. Northern is resistant to some races of leaf rust (caused by $P$. triticina Eriks.) based on seedling evaluations of the $2013 \mathrm{NRPN}$ and is postulated to carry $\operatorname{Lrl}$ and $\operatorname{Lr} 14 a$. Northern is resistant to stripe rust based on field observations in Montana (Table 1) and screening at Pullman and Mount Vernon, WA, over multiple years. Northern is susceptible to Cephalosporium stripe (caused by Cephalosporium gramineum Y. Nisik. \& Ikata) and eyespot [caused by Oculimacula acuformis (Boerema, R. Pieters, \& Hamers) Crous $\&$ W. Gams and O. yallundae (Wallwork \& Spooner) Crous \& W. Gams], based on a field trial in Pullman in 2014.

\section{End-Use Quality}

Based on experimental milling using a Brabender Automat Mill, flour yield of Northern is intermediate, with relatively high flour ash content and relatively high flour protein (Table 2). Northern has intermediate dough mixing characteristics with medium water absorption and a relatively short mixing time. Baking qualities of Northern are within acceptable ranges, with high loaf volume similar to currently deployed Montana cultivars (Table 2). Northern has relatively low polyphenol oxidase activity (Table 2) and average to good Asian noodle brightness (L24) and color stability (data not shown). Northern carries the $2^{*}$ subunit at the $G l u-A 1$ locus, the $7+8$ subunits at the Glu-BI locus, and the 5+10 subunits at the Glu-DI locus. Northern does not carry either the T1BL.1RS or T1AL·1RS translocation (marker analysis; 2013 NRPN).

\section{Availability}

The Montana Agricultural Experiment Station will maintain breeder seed of Northern. US Plant Variety Protection for Northern will be sought. A research fee will be assessed on all registered and certified seed sales. All seed requests should be sent to the corresponding author during the period of protection by the Plant Variety Protection Certificate. Seed of this release is deposited in the National Plant Germplasm System, where it will be available after the expiration of the Plant Variety Protection for research purposes, including development and commercialization of new cultivars. It is requested that appropriate recognition be made if this germplasm contributes to the development of new germplasm or cultivars.

Northern was developed with financial support of the Montana Agricultural Experiment Station, the Montana Wheat and Barley Committee, and Hatch project MONB00298. The authors wish to acknowledge the technical assistance of Ron Ramsfield, Ron Larson, Jackie Kennedy, and Harvey Teslaa.

Table 2. Average milling and baking quality attributes of hard red winter wheat cultivar Northern and check cultivars in 12 Montana environments, 2011-2013.

\begin{tabular}{|c|c|c|c|c|c|c|c|c|}
\hline Cultivar & $\begin{array}{l}\text { Polyphenol } \\
\text { oxidase }\end{array}$ & $\begin{array}{c}\text { SKCS } \\
\text { hardness }\end{array}$ & Flour yield & $\begin{array}{l}\text { Flour } \\
\text { protein }\end{array}$ & Flour ash & $\begin{array}{l}\text { Baking mix } \\
\text { time }\end{array}$ & $\begin{array}{c}\text { Baking } \\
\text { absorption }\end{array}$ & $\begin{array}{c}\text { Loaf } \\
\text { volume }\end{array}$ \\
\hline & & & 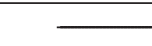 & $\mathrm{g} 100 \mathrm{~g}^{-1}$ & 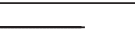 & $\min$ & $\mathrm{g} 100 \mathrm{~g}^{-1}$ & $\mathrm{~cm}^{3}$ \\
\hline Northern & 0.115 & 89 & 67.3 & 11.3 & 0.44 & 6.1 & 71.0 & 1065 \\
\hline Yellowstone & 0.217 & 81 & 67.3 & 11.0 & 0.43 & 14.2 & 73.7 & 1061 \\
\hline CDC Falcon & 0.361 & 76 & 63.2 & 11.0 & 0.44 & 9.4 & 70.8 & 1060 \\
\hline Decade & 0.317 & 82 & 66.4 & 11.3 & 0.42 & 16.1 & 74.9 & 1043 \\
\hline Jagalene & 0.332 & 83 & 68.3 & 10.8 & 0.41 & 7.2 & 70.3 & 1042 \\
\hline Colter & 0.299 & 82 & 66.9 & 11.0 & 0.42 & 15.5 & 73.7 & 1023 \\
\hline LSD (0.05) & 0.038 & 3 & 0.7 & 0.3 & 0.01 & 1.9 & 1.1 & ns \\
\hline
\end{tabular}

† Single kernel characterization system. 


\section{References}

American Association of Cereal Chemists International. 2000. AACC approved methods. 11th ed. American Association of Cereal Chemists International, St. Paul, MN.

Berg, J.E., D.M. Wichman, K.D. Kephart, J.L. Eckhoff, R.N. Stougaard, P.F. Lamb, J.H. Miller, D.L. Nash, W.E. Grey, M. Johnston, D. Gettel, R Larson, Y. Jin, J.A. Kolmer, X. Chen, G. Bai, and P.L. Bruckner. 2014. Registration of 'Colter' wheat. J. Plant Reg. 8:285-287. doi:10.3198/ jpr2014.02.0011crc

Bruckner, P.L., J.E. Berg, N. Riveland, J.L. Eckhoff, D.M. Wichman, K.D. Kephart, G.R. Carlson, G.D. Kushnak, R.N. Stougaard, D.L. Nash, W.E Grey, A.T. Dyer, Y. Jin, and X. Chen. 2007. Registration of 'Yellowstone' wheat. J. Plant Reg. 1:18-19. doi:10.3198/jpr2006.12.0788crc

Bruckner, P.L., G.A. Taylor, R.N. Stougaard, G.D. Jackson, G.R. Carlson, J.L. Eckhoff, G.D. Kushnak, G.F. Stallknect, D.M. Wichman, H.F. Bowman, D.E. Mathre, E.A. Hockett, and C.F. McGuire. 1996. Registration of Nuwest wheat. Crop Sci. 36:209. doi:10.2135/cropsci1996.0011183X0 $03600010044 \mathrm{x}$
Grant, M.N. 1980. Registration of Norstar wheat. Crop Sci. 20:552. doi:10.2135/cropsci1980.0011183X002000040042x

Riveland, N.R., J.E. Berg, K.D. Kephart, D.M. Wichman, G.R. Carlson, G.D. Kushnak, R.N. Stougaard, J.L. Eckhoff, D.L. Nash, M. Johnston, W.E Grey, Y. Jin, X. Chen, and P.L. Bruckner. 2011. Registration of 'Decade' wheat. J. Plant Reg. 5:345-348. doi:10.3198/jpr2011.04.0191crc

Taylor, G.A., H.F. Bowman, D.M. Wichman, G.R. Carlson, J.L. Eckhoff, C.F McGuire, G.F. Stallknect, G.D. Kushnak, V.R. Stewart, G.D. Jackson, E.A. Hockett, and P.L. Bruckner. 1995. Registration of 'Judith' wheat. Crop Sci. 35:1512-1513. doi:10.2135/cropsci1995.0011183X003500050 060x

Wichman, D.M., P.L. Bruckner, J.E. Berg, G.R. Carlson, G.F. Stallknect, J.L. Eckhoff, R.N. Stougaard, G.D. Kushnak, H.F. Bowman, R.H. Johnston, K.A. Tilley, G.A. Taylor, E.A. Hockett, D.V. McVey, and J.H. Hatchett. 1997. Registration of Erhardt wheat. Crop Sci. 37:1004-1005. doi:10.2135/cropsci1997.0011183X003700030053x 